\title{
Prevalence of $A_{2}$ and $A_{2} B$ Subgroups and Anti- $A_{1}$ Antibody in Blood Donors in Jazan, Saudi Arabia
}

This article was published in the following Dove Press journal:

International Journal of General Medicine

\author{
Muhammad Saboor (D) ${ }^{1,2}$ \\ Amtuz Zehra ${ }^{3}$ \\ Hassan A Hamali \\ Amr Jamal Halawani (D) \\ Abdullah A Mobarki' \\ Aymen M Madkhali' \\ Saleh Abdullah (D) \\ 'Department of Medical Laboratory \\ Technology, Faculty of Applied Medical \\ Sciences, Jazan University, Jazan, Saudi \\ Arabia; ${ }^{2}$ Medical Research Centre \\ (MRC), Jazan University, Jazan, Saudi \\ Arabia; ${ }^{3}$ Basic Science Department, King \\ Saud Bin Abdulaziz University, Al Ahasa \\ Branch, Saudi Arabia
}

Purpose: $A_{2}$ and $A_{2} B$ are rare phenotypes of the $A B O$ blood group system. Some individuals with $A_{2}$ and $A_{2} B$ may have anti- $A_{1}$ antibodies that may be clinically significant or insignificant. The aim of this study was to determine the frequency of $\mathrm{A}_{2}, \mathrm{~A}_{2} \mathrm{~B}$ phenotypes and anti- $\mathrm{A}_{1}$ antibodies in blood donors in Jazan, Saudi Arabia. This study also evaluated the reactivity potential of anti- $\mathrm{A}_{1}$ antibodies.

Materials and Methods: Blood samples collected from 446 blood donors were typed for ABO (cell and serum grouping) and Rh D. Individuals with blood group A and AB were further subtyped by testing with anti- $A_{1}$ lectin. In addition to the serum grouping using $A_{1}$ red cells, $A_{2}$ and $A_{2} B$ individuals were screened for the presence of anti- $A_{1}$ in their sera against $\mathrm{A}_{1}$ red cells at $4^{\circ} \mathrm{C}, 22^{\circ} \mathrm{C}$ and $37^{\circ} \mathrm{C}$ to determine the thermal amplitude of the reacting anti- $\mathrm{A}_{1}$ antibody (if present).

Results: Among $\mathrm{A}$ and $\mathrm{AB}, \mathrm{A}_{1}$ was the commonest phenotype $(20.2 \%, \mathrm{n}=90$ out of 446$)$ while $\mathrm{A}_{1} \mathrm{~B}$ was found to be $1.8 \%(n=8)$ among $\mathrm{AB}$ phenotype. $\mathrm{A}_{2}$ and $\mathrm{A}_{2} \mathrm{~B}$ were found to be $2.2 \%(n=10)$ and $0.9 \%(n=4)$, respectively. Only one individual with $A_{2} B$ blood type showed cold reactive anti- $\mathrm{A}_{1}$ antibody, the strength of which was 32 .

Conclusion: $\mathrm{A}_{2}$ and $\mathrm{A}_{2} \mathrm{~B}$ were the rarest among $\mathrm{ABO}$ phenotypes in the studied population. Although rare, anti- $A_{1}$ antibody is not so uncommon. Care shall be taken during routine $\mathrm{ABO}$ grouping especially in cases of mix-field or weak positive reactions in $\mathrm{A}$ and $\mathrm{AB}$ phenotypes.

Keywords: ABO, anti- $\mathrm{A}_{1}$, subgroups, blood groups, antibodies, Saudi Arabia

\section{Introduction}

The International Society for Blood Transfusion (ISBT) has recognized 346 blood group antigens. Out of these 346 antigens, 308 have been designated in 36 blood group systems while 38 are still not assigned to any blood group system. ${ }^{1}$ Among all human blood group systems, ABO (ISBT designation 001) also known as histo-blood group system, is at the center of the stage. ABO blood group antigens are found on the surface of red cells, platelets, lymphocytes and cells in the vascular endothelium, intestine, cervices, urethra, and mammary glands. ABO antigens are also found in soluble form in secretions including saliva, tears, and milk. ${ }^{2}$ This blood group is equally important in blood and/or blood component transfusion, hematopoietic stem cell and organ transplantation. This significance is due to the presence of "naturally occurring IgM anti-A, anti-B or anti-AB" antibodies produced by stimulated B cells directly without the assistance of helper $\mathrm{T}$ cells and thymus dependence against environmental agents in individuals they lack the corresponding antigen. Mismatch blood transfusion can cause severe clinical manifestations.
Correspondence: Muhammad Saboor Department of Medical Laboratory Technology, Faculty of Applied Medical Science, Jazan University, Jazan, Saudi Arabia

Tel +966544959029

Email msaboor@jazanu.edu.sa 
Major $\mathrm{ABO}$ blood group antigens are $\mathrm{A}, \mathrm{B}, \mathrm{AB}$ and O. $A_{2}$ and $A_{2} B$ are rare subtypes of $A B O$ blood group system. Other less prevalent subtypes of $A$ include $A_{3}, A_{x}$, $A_{\text {end }}, A_{y}$ and $A_{e l}$. Differences between $A_{1}$ and $A_{2}$ are quantitative as well as qualitative. Qualitative difference of $A_{1}$ and $\mathrm{A}_{2}$ lies in their chemical structures. Individuals with A phenotype express $A^{\mathrm{a}}, \mathrm{A}^{\mathrm{b}}, \mathrm{A}^{\mathrm{c}}$ and $\mathrm{A}^{\mathrm{d}}$ determinants while $\mathrm{A}_{2}$ have only $\mathrm{A}^{\mathrm{a}}$ and $\mathrm{A}^{\mathrm{b}}$ antigenic determinants. Absence of $\mathrm{A}^{\mathrm{c}}$ and $\mathrm{A}^{\mathrm{d}}$ is assumed to be a cause of development of anti- $A_{1}$ in $A_{2}$ and $A_{2} B$ individuals. ${ }^{2-4}$ Usually anti- $A_{1}$ exist as naturally occurring IgM with a thermal amplitude of less than $25^{\circ} \mathrm{C}$. However, cases of anti- $\mathrm{A}_{1}$ reacting at $37^{\circ}$ $\mathrm{C}$ have also been reported in the literature. ${ }^{5,6}$ Anti- $\mathrm{A}_{1}$ is important as it is one of the causes of $\mathrm{ABO}$ discrepancies, it can develop hemolytic transfusion reaction and its clinical manifestations have also been reported in hemopoietic stem cell and organ transplantation. ${ }^{7,8}$

To the best of the authors' knowledge no local study has been conducted to evaluate the frequency of $\mathrm{A}_{2}, \mathrm{~A}_{2}$ $B$ phenotypes and anti- $\mathrm{A}_{1}$ in normal individuals in Saudi Arabia. The aim of this study was to determine the frequency of $A_{2}, A_{2} B$, and anti- $A_{1}$ in blood donors in Jazan, Saudi Arabia. Furthermore, this study also evaluated the reactivity potential of anti- $\mathrm{A}_{1}$ antibodies.

\section{Materials and Methods}

This was a cross sectional study conducted at the Department of Medical Laboratory Technology, Faculty of Applied Medical Sciences, Jazan University, Jazan, Saudi Arabia. This study was approved by the Jazan Hospital Institutional Review Board and was conducted in accordance with the Declaration of Helsinki. Students who donated blood during the blood donation camp arranged in the Faculty of Applied Medical Sciences were requested to participate voluntarily in the study. Blood samples were collected, after informed written consent, in EDTA anticoagulated tubes and red top tubes for serology. Blood donors were male students aged $20 \pm 1.5$ years. None of the blood donors had a clinical history of any hereditary blood disorders, had a major history during the previous year or were on medication at the time of blood donation.

All samples were typed for $\mathrm{ABO}$ (cell and serum grouping) and $\mathrm{Rh}$ status by tube method using commercially available antisera (Bio-Rad, DiaMed GmbH, Switzerland). Individuals with blood group $\mathrm{A}$ and $\mathrm{AB}$ were further subtyped by testing with anti-A1 lectin (BioRad, DiaMed GmbH, Switzerland) to classify them into
$A_{1}, A_{2}, A_{1} B$, and $A_{2} B$. In addition to the serum grouping using $A_{1}$ red cells, $A_{2}$ and $A_{2} B$ individuals were screened for the presence of anti- $\mathrm{A}_{1}$ in their sera against $\mathrm{A}_{1}$ red cells at $4{ }^{\circ} \mathrm{C}, 22^{\circ} \mathrm{C}$ and $37^{\circ} \mathrm{C}$ to determine the thermal amplitude of the reacting anti- $\mathrm{A}_{1}$ antibody (if present). After incubation the cell-serum suspension was washed, treated with antihuman globulin (AHG) and results were interpreted. Sample positive for antibody was tested for the strength of reactivity. In a semi quantitative method serum was serially $(1: 1,1: 2,1: 4,1: 8,1: 16,1: 32 \ldots)$ diluted and reacted with A1 red cells. Reaction in the last tube showing agglutination was noted as the titer of the antibody.

Statistical analysis was carried out through Statistical Package for the Social Sciences (SPSS version 25 IBM Corporation, Armonk, NY, USA). For the estimation of frequencies, descriptive statistics were used.

\section{Results}

A total of 446 normal healthy blood donors were typed for $\mathrm{ABO}$ and $\mathrm{Rh}$ blood grouping. Results of $\mathrm{ABO}$ and $\mathrm{Rh}$ typing are shown in Table 1. Among 446 individuals, a total of 100 were typed as A while 12 individuals were $\mathrm{AB}$. Subtyping of $\mathrm{A}$ and $\mathrm{AB}$ showed 90 individuals (20.2\%) to be $A_{1}$ while 10 (2.24\%) were $A_{2}$ as shown in Table 2. Results of subtyping of $A B$ are shown in Table 2.

During the $\mathrm{ABO}$ typing, one sample of $\mathrm{A}_{2} \mathrm{~B}$ individual showed mix-field reaction in serum grouping with $\mathrm{A} 1 \mathrm{red}$ cells. Antibody screening of all $\mathrm{A}_{2}$ and $\mathrm{A}_{2} \mathrm{~B}$ individuals also showed only one individual with $\mathrm{A}_{2} \mathrm{~B}$ blood positive for anti- $\mathrm{A}_{1}$ at $4{ }^{\circ} \mathrm{C}$ while weakly reactive at $22^{\circ} \mathrm{C}$. No agglutination was observed in the prewarm tubes. Antibody titration of the serum of the individual with $A_{2}$ $B$ blood type having anti- $\mathrm{A}_{1}$ antibody showed a strength of 32 at $4{ }^{\circ} \mathrm{C}$ while only weak reactivity at $22^{\circ} \mathrm{C}$.

Table I The Frequency of ABO Blood Typing of the Study Population

\begin{tabular}{|l|l|l|l|l|l|l|}
\hline \multirow{2}{*}{ ABO Phenotype } & \multicolumn{2}{l|l}{$\begin{array}{l}\text { Rh (D) } \\
\text { Positive }\end{array}$} & \multicolumn{2}{l|}{$\begin{array}{l}\text { Rh (D) } \\
\text { Negative }\end{array}$} & \multicolumn{2}{l|}{ Total } \\
\cline { 2 - 7 } & $\mathbf{n}$ & $\%$ & $\mathbf{n}$ & $\%$ & $\mathbf{n}$ & $\%$ \\
\hline A & 96 & 21.52 & 4 & 0.9 & 100 & 22.42 \\
B & 100 & 22.42 & 4 & 0.9 & 104 & 23.32 \\
AB & 10 & 2.24 & 2 & 0.45 & 12 & 2.69 \\
O & 224 & 50.22 & 6 & 1.35 & 230 & 51.57 \\
Total & 430 & 96.4 & 16 & 3.6 & 446 & 100 \\
\hline
\end{tabular}


Table 2 Distribution of $A$ and $A B$ Subgroups Among the Study Population

\begin{tabular}{|l|l|l|l|}
\hline ABO Phenotypes & Subgroup & Frequency & Percentage \\
\hline$A$ & $\mathrm{~A}_{1}$ & 90 & 20.2 \\
& $\mathrm{~A}_{2}$ & 10 & 2.2 \\
\hline $\mathrm{AB}$ & $\mathrm{A}_{1} \mathrm{~B}$ & 8 & 1.8 \\
& $\mathrm{~A}_{2} \mathrm{~B}$ & 4 & 0.9 \\
\hline \multicolumn{2}{|l}{ Total } & 112 & 25.14 \\
\hline
\end{tabular}

\section{Discussion}

Among $\mathrm{ABO}$ blood group antigens, $\mathrm{A}_{2}$ and $\mathrm{A}_{2} \mathrm{~B}$ are rare phenotypes. These two phenotypes are differentiated from $A_{1}$ and $A_{1} B$ on the basis of positive reaction with anti- $A_{1}$ lectin. In this study, 446 samples were tested for $A B O$ typing and subtyping. Group $\mathrm{O}$ was the most common phenotype $(51.57 \%)$. Phenotypes $\mathrm{A}, \mathrm{B}$ and $\mathrm{AB}$ were $22.4 \%, 23.3 \%$ and $2.7 \%$ respectively. The majority of the subjects $(96.4 \%)$ of this study were $\mathrm{Rh} \mathrm{D}$ positive and the remaining 3.6\% were $\mathrm{Rh} \mathrm{D}$ negative. Among $\mathrm{A}$ and $\mathrm{AB}$, $\mathrm{A}_{1}(20.2 \%)$ was the commonest phenotype while $\mathrm{A}_{1} \mathrm{~B}$ was found to be $1.8 \%$ among $A B$ phenotype. $\mathrm{A}_{2}$ and $\mathrm{A}_{2} \mathrm{~B}$ were found to be $2.24 \%$ and $0.9 \%$ respectively. $A_{1}, A B$ and $\mathrm{O}$ phenotyping results are similar to the locally conducted studies $^{9-14}$ except one ${ }^{15}$ that reports the highest frequency of O (62\%), and lower frequency of B (8.7\%) as compared to the current study and all other studies.

It should be noted that to date none of the studies conducted in Saudi Arabia has reported the prevalence of $\mathrm{A}_{2}$ and $\mathrm{A}_{2} \mathrm{~B}$. This was the first study that reported the frequencies of $A_{2}$ and $A_{2} B$. The results of the current study shows that $A_{2}$ and $A_{2} B$ are rare phenotypes.

Among $A_{2}$ and $A_{2} B$ individuals, only one donor showed mix-field reaction in serum grouping raising the suspicion of IgM anti- $A_{1}$ in the study population. This observation was strengthened by the presence of agglutination $(2+)$ in the test tubes incubated at $4^{\circ} \mathrm{C}$, while only weak reactivity at $22^{\circ} \mathrm{C}$. The antibody was demonstrable after incubation at $4{ }^{\circ} \mathrm{C}$ and $22^{\circ} \mathrm{C}$ indicating its $\operatorname{IgM}$ nature. None of the $A_{2}$ individuals was positive for anti- $A_{1}$. The strength of anti- $\mathrm{A}_{1}$ reaction was 32 after incubation at $4{ }^{\circ} \mathrm{C}$. Strength of antibody demonstrates it significance in transfusion practices especially when the thermal amplitude of the reacting antibody is high. In this case, the reactivity was not enhanced at $37^{\circ} \mathrm{C}$ and showed weak reactivity at a titer of 8 while no reactivity at 16 and beyond. Cold reactive anti- $A_{1}$ has been reported in the literature. ${ }^{16}$ The literature shows the prevalence of anti- $\mathrm{A}_{1}$ among $\mathrm{A}_{2}$ and $\mathrm{A}_{2} \mathrm{~B}$ to be $1-8 \%$ and $22-35 \%$ respectively. $^{2-4}$ Chaudhari et al, (2008) has reported a case of IgG anti- $\mathrm{A}_{1} \cdot{ }^{17}$ Similarly, two other studies have shown hemolytic transfusion reaction due to anti- $\mathrm{A}_{1} \cdot{ }^{18,19}$ Development of anti- $\mathrm{A}_{1}$ antibodies after allogeneic stem cell transplantation and organ transplantation has also been reported. ${ }^{7,20}$

It has been reported that individuals with $\mathrm{A}_{2} \mathrm{~B}$ phenotype are more prone to develop anti- $A_{1}$ as compared to $A_{2}$. This could be explained on the basis of two observations. Firstly, individuals with $\mathrm{A}_{2} \mathrm{~B}$ have a smaller number of $\mathrm{A}$ antigens in comparison to $\mathrm{A}_{2}$. Secondly, $\mathrm{A}_{2} \mathrm{~B}$ individuals possess *R101 allele more commonly than $A_{2}$ individuals ( $41 \%$ vs $1 \%$ ) leading to the high frequency of $\mathrm{A}_{2} \mathrm{~B}$ phenotype. ${ }^{21}$

From a transfusion perspective, individuals with $A_{2}$ and $\mathrm{A}_{2} \mathrm{~B}$ should be transfused with identical blood types. However, due to its rarity especially $\mathrm{A}_{2} \mathrm{~B}$, special attention shall be given if identical blood type is not available and the patient needs transfusion of packed red cells. These individuals can be transfused with $\mathrm{O}$ group packed red cells considering it the next compatible group.

A major limitation of this study may be the small sample size due to which no anti- $\mathrm{A}_{1}$ antibody was demonstrated in $\mathrm{A}_{2}$ individuals.

\section{Conclusion}

In conclusion the prevalence of anti- $\mathrm{A}_{1}$ in $\mathrm{A}_{2}$ and $\mathrm{A}_{2} \mathrm{~B}$ is rare. It is important to rule out the possibility of its wide range of thermal reactivity. Any discrepancy in these individuals should be resolved before blood/component transfusion.

\section{Acknowledgments}

Authors are thankful to the blood donors who donated and participated in the study.

\section{Disclosure}

The authors report no conflicts of interest in this work.

\section{References}

1. Storry JR, Castilho L, Daniels G, et al. International Society of Blood Transfusion working party on red cell immunogenetics and terminology: report of the Seoul and London meetings. ISBT Sci Ser. 2016;11:118-122.

2. Hod EA, Spitalink PF, Spitalink SL, Jude JW. Carbohydrate blood groups. In: Simon T, Snyder E, Solheim B, Stowell C, Strauss RPM, editors. Rossi's Principles of Transfusion Medicine. 4th ed. Bethesda: Blackwell; 2009:89-109. 
3. Harmening DM, Manning BL, editor. Modern Blood Banking \& Transfusion Practices. 7th ed. Philadelphia: F.A. Davis; 2019:119-148.

4. Cooling L. Chapter 12: ABO, H, and Lewis blood groups and structually related antigens. In: Fung $M$, Grossman $B$, Hillyer CWC, editors. Technical Manual. 18th ed. Bethesda: AABB; 2014:290-315.

5. Domen RE, Calero A, Keehn WH. Acute hemolytic transfusion reaction report of a case. Transfus Med. 1988;19(11):739-740.

6. Northoff H, Wölpl A, Sugg U, et al. An unusual sample of irregular anti-A1, probably causing an early delayed transfusion reaction. Blut. 1986;52(5):317-321. doi:10.1007/BF00320795

7. Bracey AW, Van Buren C. Immune anti-A1 in A2 recipients of kidneys from group O donors. Transfusion. 1986;26(3):282-284. doi:10.1046/j.1537-2995.1986.26386209389.x

8. Akkök ÇA, Haugaa H, Galgerud A, Brinch L. Severe hemolytic transfusion reaction due to anti-A1 following allogeneic stem cell transplantation with minor ABO incompatibility. Transfus Apher Sci. 2013;48(1):63-66. doi:10.1016/j.transci.2012.07.006

9. Elsayid M, Aseeti Y, Al Saqri F, Alanazi AQS. A study of prevalence of blood group of Saudi patients in King Abdulaziz Medical City-Riyadh. Sci J Public Health. 2015;3(4):559-562. doi:10.11648/ j.sjph.20150304.25

10. Zaghloul A, Aljoaid AM, Balkhi DS, et al. Frequency of AbO blood groups in the Makkah City and their association with diseases. Indo Am J Pharm Sci. 2019;6(1):551-557.

11. Owaidah AY, Naffaa NM, Alumran A, Alzahrani F. Phenotype frequencies of major blood group systems (Rh, kell, kidd, duffy, mns, p, Lewis, and Lutheran) among blood donors in the eastern region of Saudi Arabia. J Blood Med. 2020;11:59-65. doi:10.2147/JBM. S236834
12. Alabdulmonem W, Shariq A, Alqossayir F, et al. Sero-prevalence $\mathrm{ABO}$ and $\mathrm{Rh}$ blood groups and their associated transfusion-transmissible infections among blood donors in the central region of Saudi Arabia. J Infect Public Health. 2020;13 (2):299-305.

13. Al-Himaidi AR, Umar M. ABO blood group distribution among Saudi citizens related to their regional or original tribal location. Kuwait J Sci Eng. 2002;29(1):75-81.

14. Junainah E, Al-Amoudi S, Junainah J, et al. Prevalence of ABO and $\mathrm{Rh}$ blood groups in Saudi Arabian population. Life Sci J. 2016;3 (1):56.

15. Abdullah SM. Frequency of ABO and Rh blood groups in the Jazan region of Saudi Arabia. Pak J Med Sci. 2010;26(4):818-821.

16. Shastry S, Bhat S. Imbalance in A 2 and A 2 B phenotype frequency of ABO group in South India. Blood Transfus. 2010;8(4):267-270.

17. Chaudhari CN, Misra RN, Nagpal AK. Transfusion in blood group A 2B with anti A 1 recipient. Med J Armed Forces India. 2008;64 (4):371-372. doi:10.1016/S0377-1237(08)80029-9

18. Helmich F, Baas I, Ligthart P, et al. Acute hemolytic transfusion reaction due to a warm reactive anti-A1. Transfusion. 2018;58 (5):1163-1170. doi:10.1111/trf.14537

19. Shah KDB. The not so insignificant anti-A1 antibody: cause of severe hemolytic transfusion reaction. Am J Clin Patho. 2018;149(S):S157S161.

20. Brecher ME, Moore SB, Reisner RK, Rakela J, Krom RAF. Delayed hemolysis resulting from anti-A1 after liver transplantation. $A m$ J Clin Pathol. 1989;91(2):232-523. doi:10.1093/ajcp/91.2.232

21. Ogasawara K, Yabe R, Uchikawa M, et al. Different alleles cause an imbalance in $\mathrm{A} 2$ and $\mathrm{A} 2 \mathrm{~B}$ phenotypes of the $\mathrm{ABO}$ blood group. Vox Sang. 1998;74:242-247. doi:10.1046/j.1423-0410.1998.7440242.x
International Journal of General Medicine

\section{Publish your work in this journal}

The International Journal of General Medicine is an international, peer-reviewed open-access journal that focuses on general and internal medicine, pathogenesis, epidemiology, diagnosis, monitoring and treatment protocols. The journal is characterized by the rapid reporting of reviews, original research and clinical studies

\section{Dovepress}

across all disease areas. The manuscript management system is completely online and includes a very quick and fair peer-review system, which is all easy to use. Visit http://www.dovepress.com/ testimonials.php to read real quotes from published authors. 